\title{
Challenges And Pressures Of Mediated Images: Exploring Representation Of Postmodern Women In The Leading Magazines Of Pakistan And Understanding The Discourses Of Working Women
}

\author{
Sumera Batool \\ Department of Mass Communication \\ Lahore College for Women University \\ Sadia Majeed \\ Department of Mass Communication \\ National University of Modern Languages
}

\begin{abstract}
The study deals with the media representation of women in the post-modern era and the pressures they face by such mediated images. The study has explored the nature of identities being represented for women in magazines and has also discussed the challenges and pressures that are being faced by women in building and maintaining their own social identities. The critical issue of the feminist research has rectified the appropriateness between the constructed images of a woman, and the challenges and pressure of a working woman she faces in real. Both qualitative and quantitative aspects of media representation of women have been observed through content analysis. Thechallenges and pressures of women have been interpreted by interviewing working women. The thematic analysis of data has shown a visible difference in the mediated images of an empowered woman, and the real discourses of a working woman.
\end{abstract}

Keywords: Post-Modern Women, Challenges and Pressures, Discourse of Working Woman, Pakistani Magazines.

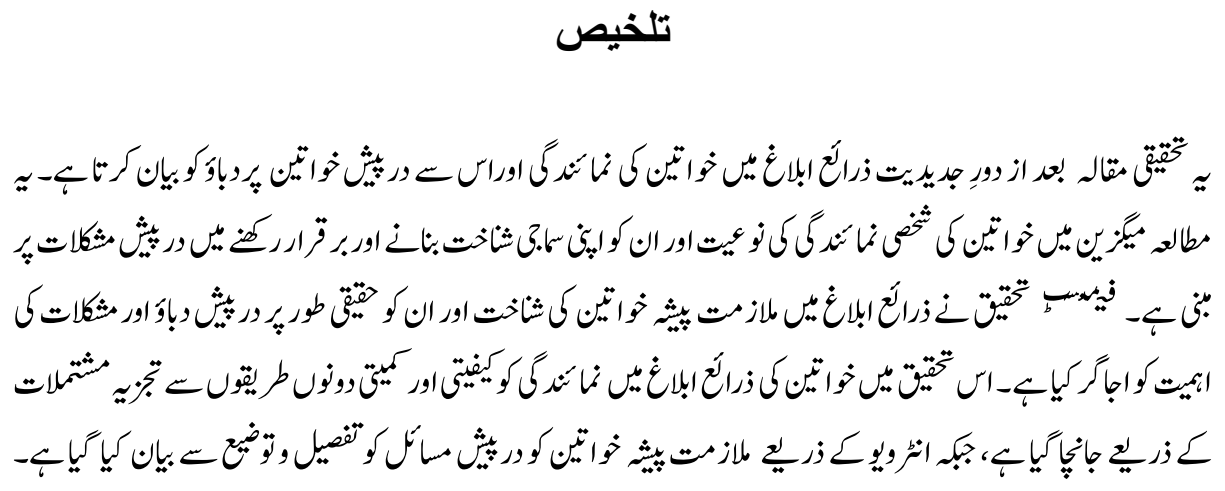


218 Challenges and Pressures of Mediated Images: Exploring Representation of Postmodern Women in the Leading Magazines of Pakistan and Understanding the Discourses of Working Women

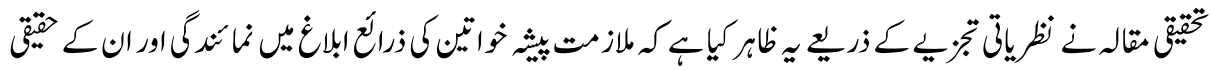

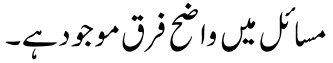

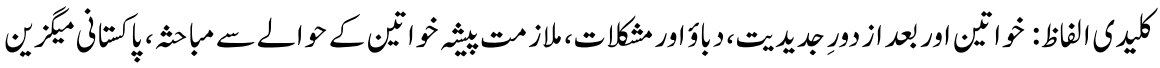

\section{Introduction}

In the modern era media has materialized as a powerful tool in structuring and restructuring the ideologies, which in turn define social identities. After the three waves of feminism from 1970 to 1980 , a visible change has come to fore regarding woman representation in the media (Sarkar, 2014). Media has a decisive role in distorting the social identities of the women folk as a perfect woman through the postmodern feminist media. Media is a powerful element and it reflects the dominant attitudes and shapes the approach as well (Yasmin \& Mangario, 2015). A woman has been systematically subordinated and the victim of complex structures of patriarchy (Zoonen, 1996). The media research regarding feminism has turned out to be a lexicon in the social sciences.

Media works as an influential force and has strong effects in shaping the minds as it cultivates the ideologies and has cognitive effects. Media is playing central role in shaping identities particularly gender roles regarding female identities. Our minds are injected continuously with such contents of media (Cashmore, 2005; Belton, 2000; Singrolli, McLeod, and Healy, 1994). The discourses of media dominate the attitudes and ideas of an individual in the society and also construct the approach and behaviours. Woman in the media is of keen interests of the communication studies researchers. Women generally represented as wife, mother and sex object (Obrach, 1978; Macrobbie, 2004; Beryl and Meyer, 1999) in media whereas she had to have an attractive personality. Media construct certain perfect images of female body and gender roles are socially constructed and reformulated (Spender, 2001; Waland Shruti, 2001; Wales, 2003; McRobbie, 2004). These socially constructed gender roles by dominant media demonstrate stereotypes in the society. Zawisza (2011) defines stereotype as the process to represent something with some specific meaning. Hall (1997) argued that the representations are the production of the concepts of our minds and languages. In advertising the woman is represented young, slim, and break stereotypes through visual images which is also a form of language and construct meaning (Gevogyen,2016) whereas women body is objectified to sell the products in adverting (Yang,2010). The ideal doll like looks of women in magazines are unrealistic and making it normal for viewers to time up with ideal. The stereotypes of beauty are generally associated with women and their plastic surgeries to become the ideal woman are the pressures that women face (Sarkar, 2014; Gerber, 2009; Dittamer, 2004). Harper and Tiggman (2008) narrate in their theory of self-objectification that magazines are promoting self- 
objectification and women are being exploited as a commodity by media owners. Media owners takes heavy amount from advertisers to run their channel or setup and advertisers sell their goods through misrepresentation of women in media in a sensual way not by narrating the characteristics and quality of goods (Shani, 2017).

Here this study tends to explore the representation of woman in the leading magazines of Pakistan. It also attempts to understand the challenges and pressures faced to women due to these mediated images of a woman in the postmodern era. The study also analyses the role of mediated identities in highlighting the discourses of the working women.

\section{Objectives}

1. To explore the nature of identities portrayed in leading magazines of Pakistan.

2. To understand the pressures and challenges faced by working women in building their own social identities.

3. To analyse whether mediated images and the pressures faced by a woman in real life are compatible.

\section{Literature Review}

Projection of women in magazines whether in advertisements or in text with images are creating mediated unrealistic identities as reality and appearances have become one which is distorted realities. Pictorial images have great effect in constructing identities (Hundley,2012 and Jain, 2011). Pictures in the magazines are edited and construct realities. Manipulation of the images in fashion magazines women is ideally resized in order to produce an ideal body (Harris and Lester, 2001; Elloit, 2003). Media characterises women in multiple roles and engenders symbolic inhalation. Many of the studies have argued that media not only shape the minds but also projects towards the adoption of celebrity culture. Significant studies showed the admirer and celebrity relationship that change their personalities according to the celebrities (Garner, 1980; Tuchman, 2000; Gorgan, 1999). These objectified mediated images attract as feminine qualities. The creative department in the women magazines is still under the control of men who present woman more seductively. Advertisements promote sexism and woman without good looks have no fame (Nagi, 2004 \& Bebrick, 2010). Woman have decorative roles, most of celebrities are known for their ideal body images which is creating identity crises for other women (Yang, 2010). Media plays a central role in maintaining social inequalities and effectiveness of womanhood lies in the cultural ideal of thinness (Eisend, 2010; Tscihla and Zoto, 2013; Devereux, 2003).

Mediated images have created so many challenges and have constructed certain social roles for women in the society. Women are managing with multiple roles in acquiring the 
excellent and outstanding status in the society. There are lot of pressures faced by women in maintaining balances in the social structures of the society (Buzzanell \& Liu, 2005). Flawless woman is the image of contemporary era. The mediated images of women in the magazines have created the myth that what to do and what not to. This formulation of flawless women by the media is big challenge for the working women in real who is coping with and want to attain these constructed images. The description of mediated images and the deconstruction of these images create discourses how an image works and create ideologies, thus promote a particular construction of the reality (Brumet, 1984 and Hall, 1997). The zero error women of media has forced women to full fill lot of social expectations. Employed women have to attain their status where expectations are over loaded. The deconstruction of realities is focus of work life learning. This socio economic state of women leads to tension, depression and anxiety in the personal and family lives of women along with physical problems (Duffy and Lilly, 2006; Muthusamy, 2009 \& Sundarsan, 2014).

The world of mass media has created a new woman. The symbolic use of a woman in the media is distorting realities of the feminine issues. Feminist critiques argue that the portrayal of a woman in the media is detached from reality, for example, the physically attractive models used in advertising produce consumer expectation of trustworthiness. Due to the excess in the glamorization and commercialization, a woman has become mandatory part for advertising. The mass media had not fulfilled its duty as an effective instrument in the process of addressing the challenges and pressures faced by a working woman (Yin, \& Pryor, 2012). The postmodern era see the modernized and upgraded standards of living in all spheres of social life. The expansion of media brought substantial and insubstantial changes in the structures and standards of the society. The cultural materialism redefined the social structures, and created challenges and pressures for women through the portrayal of mediated identities of a woman by post-feminist media particularly magazines. A gap is identified here in the existing body of literature on the paradox of women representations in media and the real life pressures and challenges faced to women due to mediated images so this study evaluated the delicate difference between the representation of postmodern woman and what is required to present by media and interpreted how these mediated identities create challenges for the working women in hybrid, fragmental, hyper mediate context of the postmodern era. Keeping in consideration the identified gap in literature this research study focused on following queries:

1. What are the most likely predominant identities represented by magazines of Pakistan?

2. Do the narratives and appearance of women in the text and pictures of magazines create any social expectations from them? 
3. Whether the media narratives of women are creating challenges in the lives of working woman in maintaining their own social identity?

\section{Theoretical Implications}

Social Identity Theory, by Henri Tajfel and John Terner prominently absorbed in 1980s, strongly focuses on how the social context of individual affects the intergroup relations (Hornsey, 2008; Stets \& Burke, 2000; Hogg, Terry \& White, 1995). Social identity theory argues that the social context of an individual defines the one's concept of self that is achieved through social comparisons. The social context or category provides the attributes to the member of the group to think, feel and behave in certain ways. It also suggests that individuals drive for positive identity by social comparisons. Whereas, Goldman (1992) argues that main economic and social institutions uphold cultural hegemony and provide us socially constructed ways of seeing and making sense of society. Identities are narratives of the self in the society. The roles and modes of behaviour have transformed from previous generations. Previous generations are considered as customary so human action is limited to those values of pre modern times. Modernism, traditions, religion science and technology are the influential factors to human identity in postmodern era. These narratives usually challenged and replaced by new cultural self-consciousness (Lyotard, 1979). Self-identity, associated with selfunderstanding, involves self believe that is "narratives of the self" (Gauntlet, 2002). These narratives are on-going construction process which cannot be created early in our lives and these identities need to be creating and continuously maintained. In postmodern culture identities of an individual are highly influenced by media in popular culture (Lull, 2000). Realities are stimulated by constitutive forces which are the reason in the simulations of identities (Baudrillard, 1994).

Media, as an important and dominated institution of the society, plays a central role in the construction of women identities as providing narratives for the self-understanding of women. The structures developed by media are internalized by the individuals. Media, operationalized here as magazines, narrate women in a way with multiple identities which is a continuous process of redefining the role of women in the society. Foucalt (1990) indicates that there is a transition in the social procedure from linear to interrelated parts of the society that constructs knowledge socially. Postmodern introduces shift from linear causality to interrelated parts which promote behaviour and thinking in circular patterns. The transitions in the content of the magazines define and redefine women identities in the patriarchal postmodern era. Postmodernism also operated that there is no single view holds much truth and focus on presenting the realities in which one could be presented (Becvar, \& Becvare, 2006). Media builds and rebuilds the identities of women and that continues the process of production and reproduction of self-understanding for the women. And ultimate narrating a self (self-identity) is the discourse of the others (Gergen, 2003). 

in the Leading Magazines of Pakistan and Understanding the Discourses of Working Women

Social Expectation Theory attempts to explain how social expectations are created through portrayals of roles of women in the media content. In the postmodern societies what audience experiences and have expectations are defined by the media (Baudrillard, 1994).

Social expectation theory provides the frame work for this research in terms of how the mediated identities of women create expectations from women to fulfil. The women are expected to meet and maintain certain standards which create exceeding pressures for woman of postmodern era. The women are expected how she should look like and how to behave. The mediated images of perfect ideal women, beauty myths and ideal body shapes and sizes for women specifically creates lots of expectations from the women that ultimately brings lots of pressures and challenges in the real lives of women to meet. The unrealistic beauty myth of media for women has created an image of women as female hero. The ideal representations of women in the magazines create a hyper realityand expectations of super women.

\section{Methodology}

Quantitative content analysis has been conducted to explore the representation of women in magazines. Universe of the study comprised of monthly English leading fashion and lifestyle magazines of Pakistan of last two years from January 2016 to December 2018. Units of Analysis include articles and pictures related to women. Three top circulated and readership magazines, 'Hello', 'She' and 'Woman Owns, have been selected by random Sampling.

\section{Operationalization of Categories}

\begin{tabular}{|l|l|l|l|}
\hline $\begin{array}{l}\text { Units of } \\
\text { analysis }\end{array}$ & $\begin{array}{l}\text { Main } \\
\text { Categories }\end{array}$ & Sub Categories & Operationalization \\
\hline \multirow{3}{*}{ Articles } & Appearances & Customary & $\begin{array}{l}\text { Continued practices which are } \\
\text { considered conventional in social } \\
\text { system are customary Women } \\
\text { conventional appearance is coded } \\
\text { under customary appearance. }\end{array}$ \\
\cline { 3 - 4 } & Non Customary & $\begin{array}{l}\text { Non- customary appearances are } \\
\text { coded under the explosive, bold } \\
\text { advents of women in the articles of } \\
\text { selected magazines. }\end{array}$ \\
\cline { 3 - 4 } & Neutral & $\begin{array}{l}\text { The articles which do not lie under } \\
\text { the categories of customary and } \\
\text { non-customary are coded as neutral. }\end{array}$ \\
\cline { 3 - 4 } & & Narratives of empowered women are \\
\hline
\end{tabular}




\begin{tabular}{|c|c|c|c|}
\hline & \multirow[t]{3}{*}{ Narratives } & Empowered & $\begin{array}{l}\text { considered as who transform their } \\
\text { identities and engage in postmodern } \\
\text { global values with identifiable } \\
\text { striking looks, derives a sense of } \\
\text { super women, perfect energies and } \\
\text { are financially empowered. }\end{array}$ \\
\hline & & Oppressed & $\begin{array}{l}\text { Oppressed women are } \\
\text { operationalized as who are } \\
\text { unprivileged, facing prejudices, } \\
\text { domestic pressures, work place } \\
\text { challenges and fail to manage the } \\
\text { life effectively. }\end{array}$ \\
\hline & & Others & $\begin{array}{l}\text { Others are considered as a neutral } \\
\text { representation of women not } \\
\text { establishing them as empowered nor } \\
\text { oppressed. }\end{array}$ \\
\hline \multirow[t]{4}{*}{ Pictures } & \multirow{4}{*}{$\begin{array}{l}\text { Camera } \\
\text { Angling }\end{array}$} & Close-Up & $\begin{array}{l}\text { Pictures with close ups representing } \\
\text { women explicitly and intimately by } \\
\text { showing the specific parts of } \\
\text { women body. }\end{array}$ \\
\hline & & Medium Shot & $\begin{array}{l}\text { The pictures with the half body } \\
\text { image of women. }\end{array}$ \\
\hline & & Long Shot & $\begin{array}{l}\text { Long shot is the complete and full } \\
\text { picture of the women. }\end{array}$ \\
\hline & & Others & $\begin{array}{l}\text { The pictures which do not come in } \\
\text { the categories of close-ups, medium } \\
\text { shot, and long shot are considered } \\
\text { as others. }\end{array}$ \\
\hline
\end{tabular}

In-depth interviews have been conducted from working women to understand the challenges and pressures of mediated images of magazines. Ten women, conveniently sampled, from top five professions of Pakistan, medicine, teaching, law, banking and information technology (Suleman, 2018), while two from each profession had been interviewed. The research opted for narrative analysis of interviews, so unstructured interviews were conducted. In this case, the interviewer attempted to obtain a detailed story from the subject about a specific event or aspect of the women life. Data was collected in face to face interviews and were recorded. The demographics of participants included age group of 30-40 and all living in Lahore.Every single interview has been denoted as transcript fromT1 to T10 adopted from (Guest, Bunce \& Johnson, 2008). 


\section{Quantitative Findings}

Table 1(a): Articles and Pictures published in 'Women's Own' magazine Unit of analysis

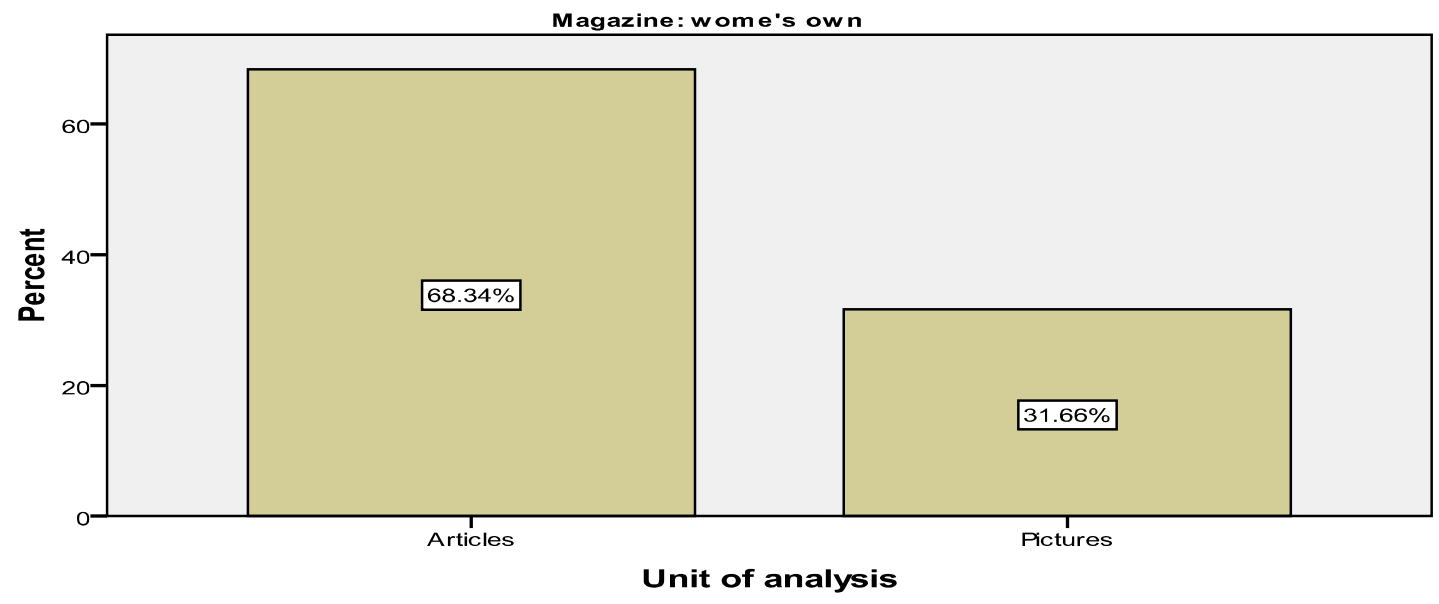

Cases weighted by data

Table 1(a) shows that there are 464 articles which are $68.3 \%$ and 215 pictures which is $31.7 \%$ of the data related to women has been published in women's own magazine.

Table 1(b): Apperances, Narratives and Camera angles of 'Women's own' magaznine

Categories

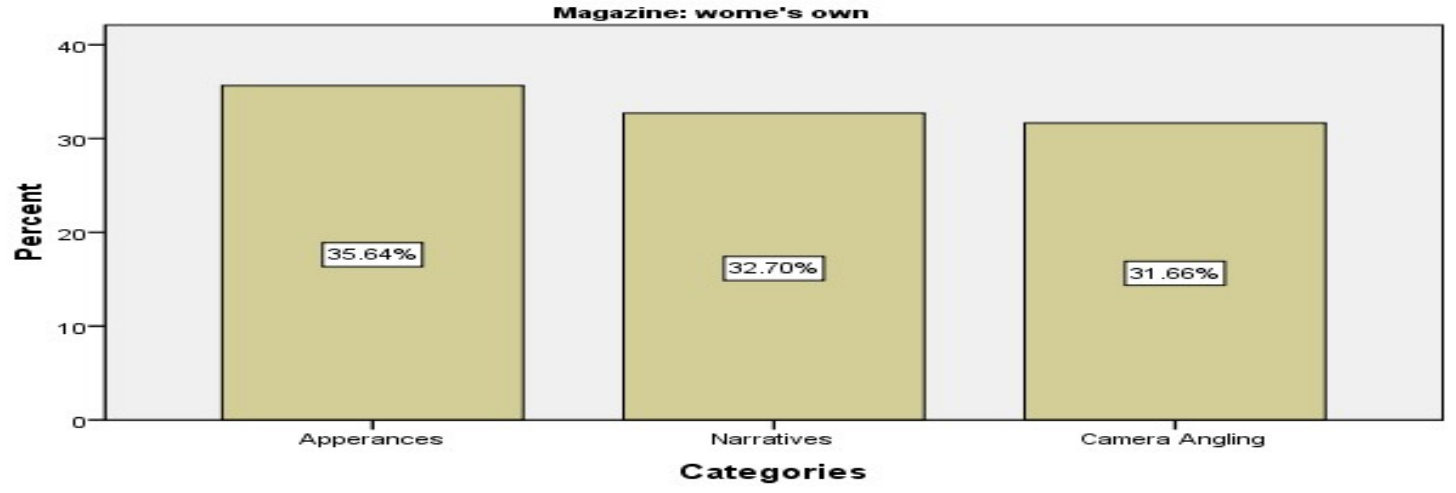

Cases weighted by data 
Table 1(c): Sub-categories of apperances, narratives and camera angles of 'Women's own' magaznine

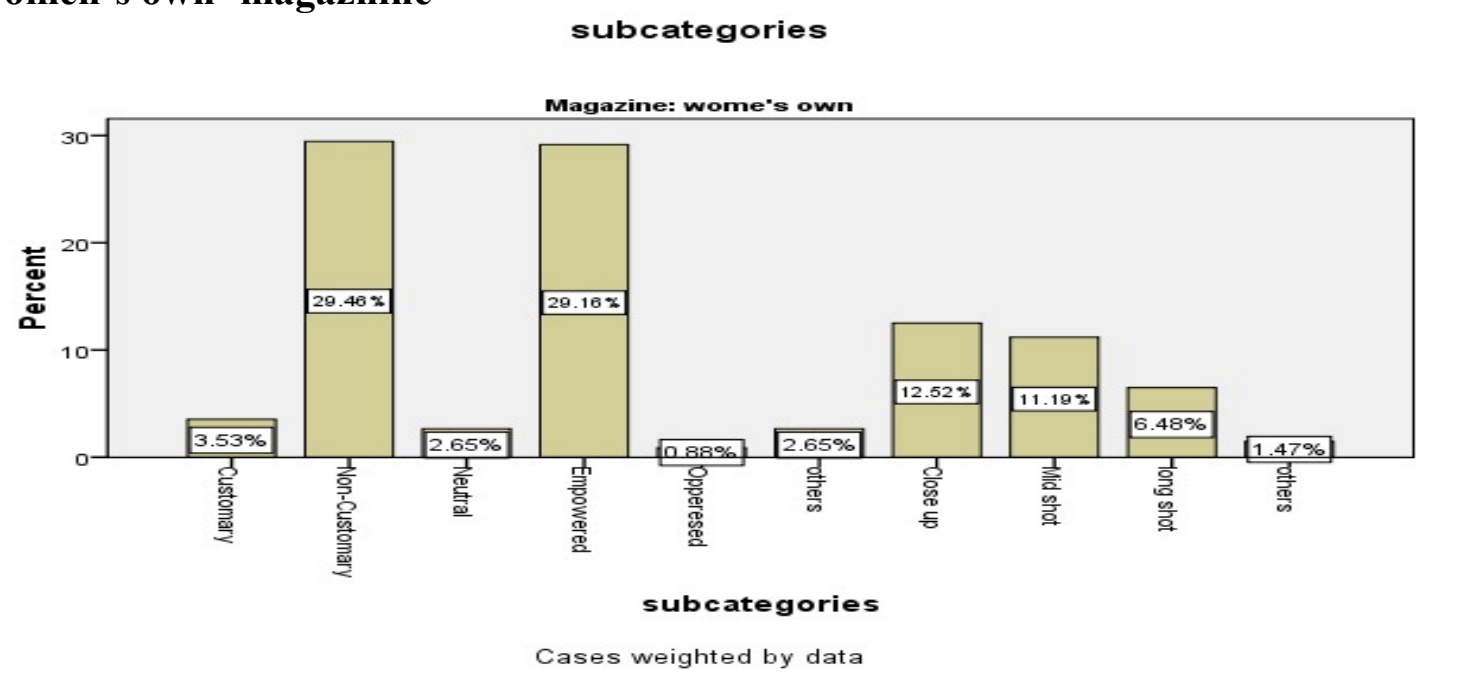

Table 1(c) shows appearances, narratives and camera angling of women's own magazine. Under the main category appearances total 242 which are $35.6 \%$ articles has published. 24 customary which are $3.5 \%, 200$ non-customary which are $29.5 \%$ and 18 neutral articles which are $2.7 \%$ have published. Under second key word narratives total 222 which are $32.7 \%$ articles have published. 198 empowered which are 29.2, 6 oppressed which are $.9 \%$ and 18 others which are 2.7 articles have published in women's own magazine. In camera angling there are total 215 which are almost $31.7 \%$ articles with 85 closes up which are $12.5 \%, 76$ mid sot which are $11.2 \%$, 44 long shot which are $6.5 \%$ and 10 others which are $1.5 \%$ have published in women's own magazine.

Table 2(a): Articles and pictures published in 'Hello' magazine Unit of analysis

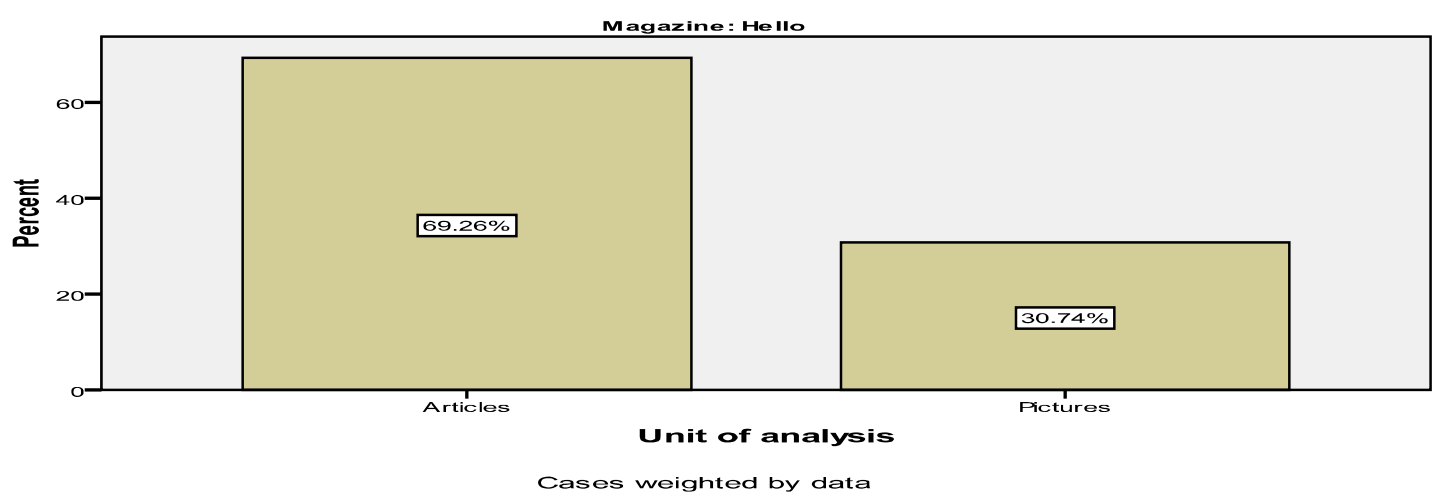


Table 2(a) of articles and picture published in "Hello" magazine shows that there are total 1259 unit of analysis including 872 which are almost $69.3 \%$ articles, including 387 pictures which are almost about $30.7 \%$ has published in Hello magazine.

Table 2(b): Appearances, Narratives and Camera Angling of 'Hello’ magazine.

Categories

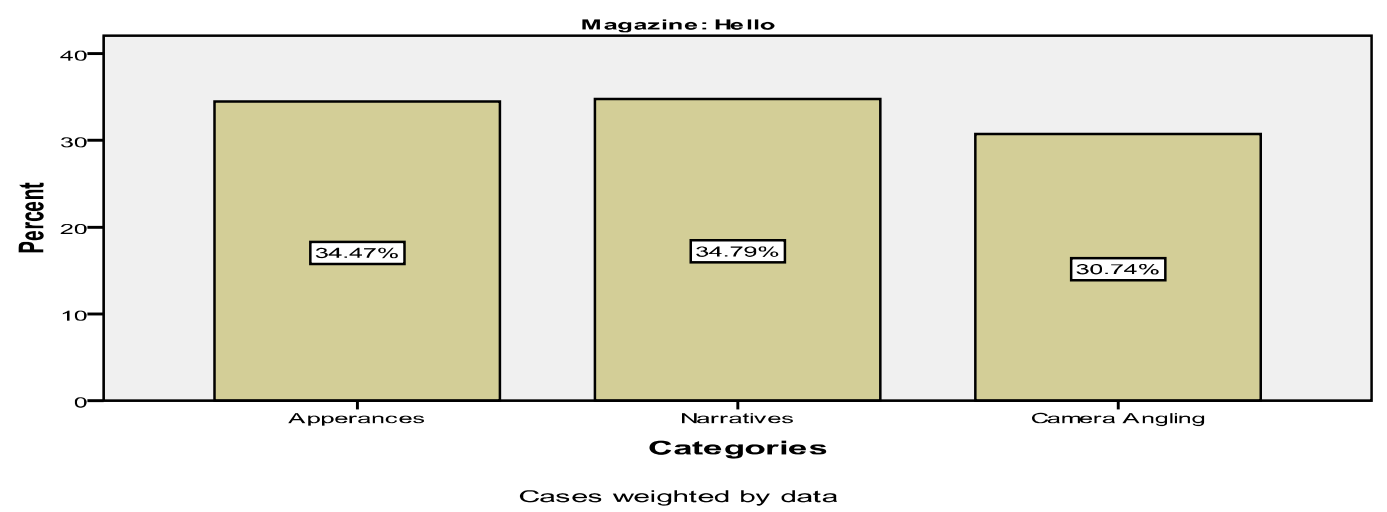

Table 2(c): Sub categories of Appearances, Narratives and Camera Angling of 'Hello' magazine.

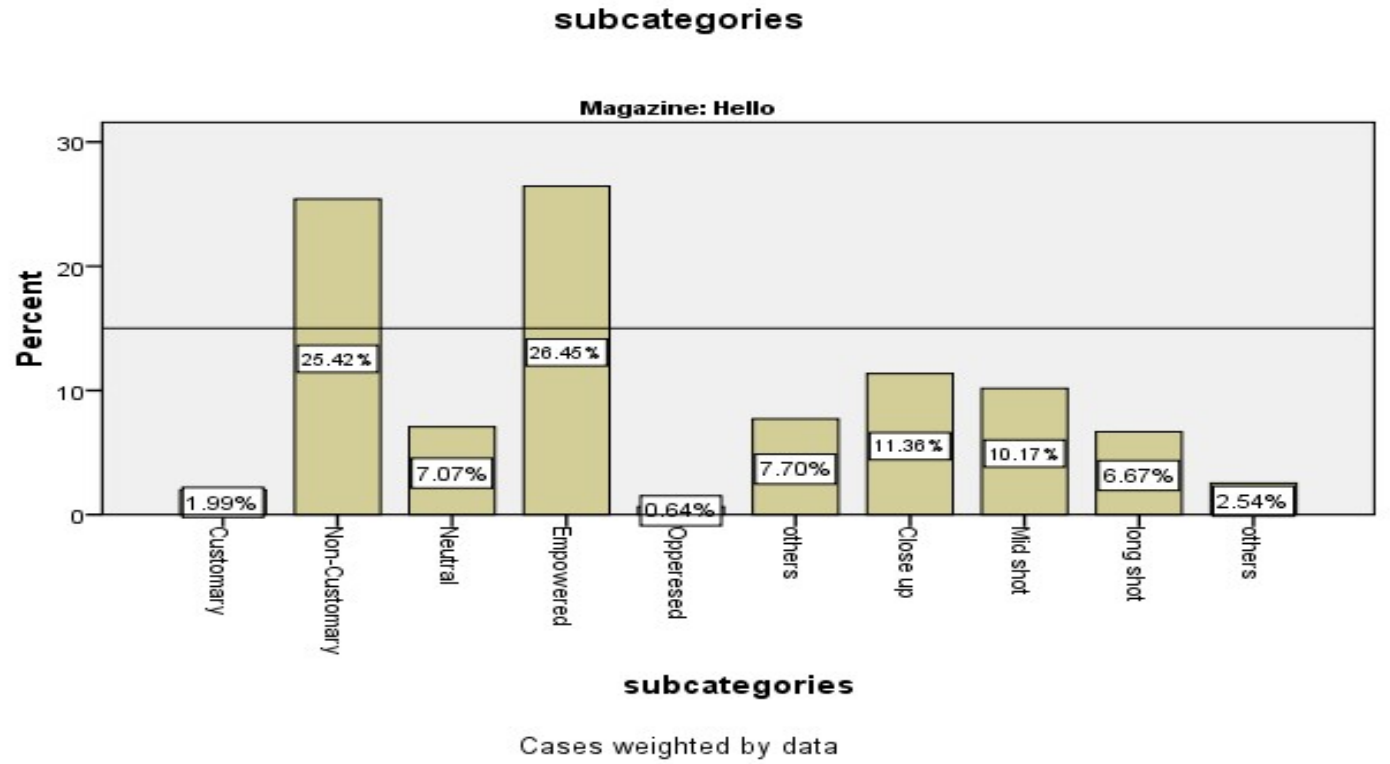

Table 2(c) of sub categories published in 'Hello' magazine show appearances, narratives and camera angling of Hello magazine. Under the main category appearances total 434 which are $34.5 \%$ articles has published, 25 customary which are $2 \%, 320$ non-customary which are $25.4 \%$ and 89 neutral articles which are $7.1 \%$. Under second key word 
narratives total438 which are $34.8 \%$ articles have published. 333 empowered which are $26.4 \%, 8$ oppressed which are, $6 \%$ and 97 others which are $7.7 \%$ articles have published in Hello magazine. In camera angling there are total 387 articles which are almost $30.7 \%$ with 143 closes up which are $11.4 \%, 128$ mid shot which are $10.3 \%, 84$ long shot which are $6.7 \%$ and 32 others which are $3.5 \%$ have published in Hello magazine.

\section{Table 3(a): Articles and pictures published in 'She' magazine}

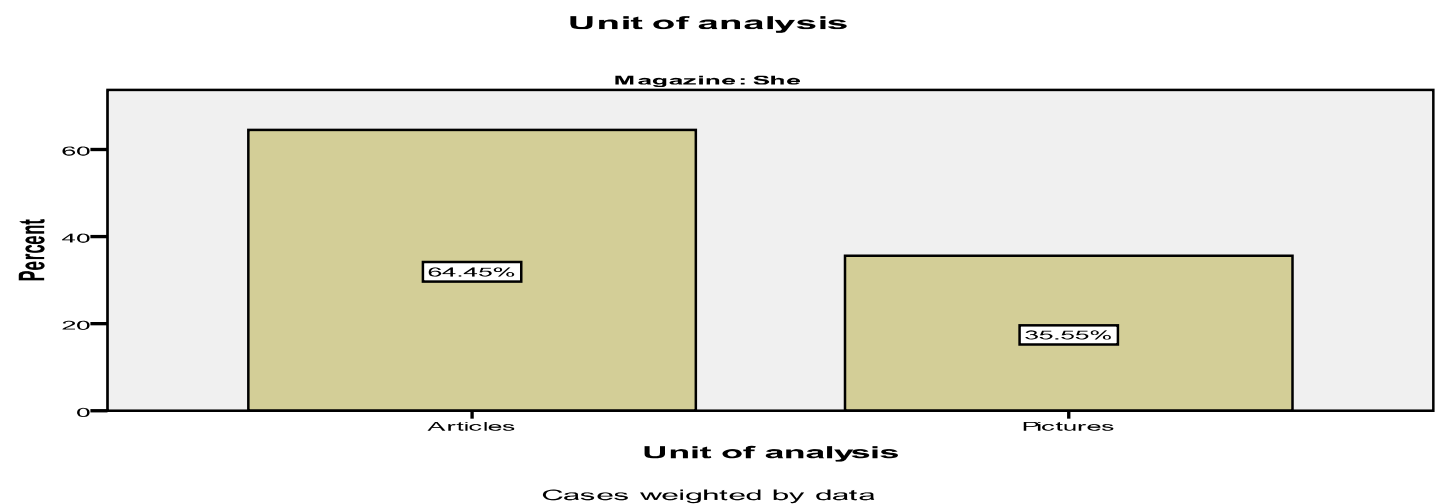

Table 3(a) of published article and pictures in 'She' magazine shows that there are total 1114 unit of analysis including 718 which are almost $64.5 \%$ articles, including 396 pictures which are almost about $35.5 \%$ has published in She magazine.

Table 3(b): Appearance, Narratives and Camera Angling of 'She' magazine Categories

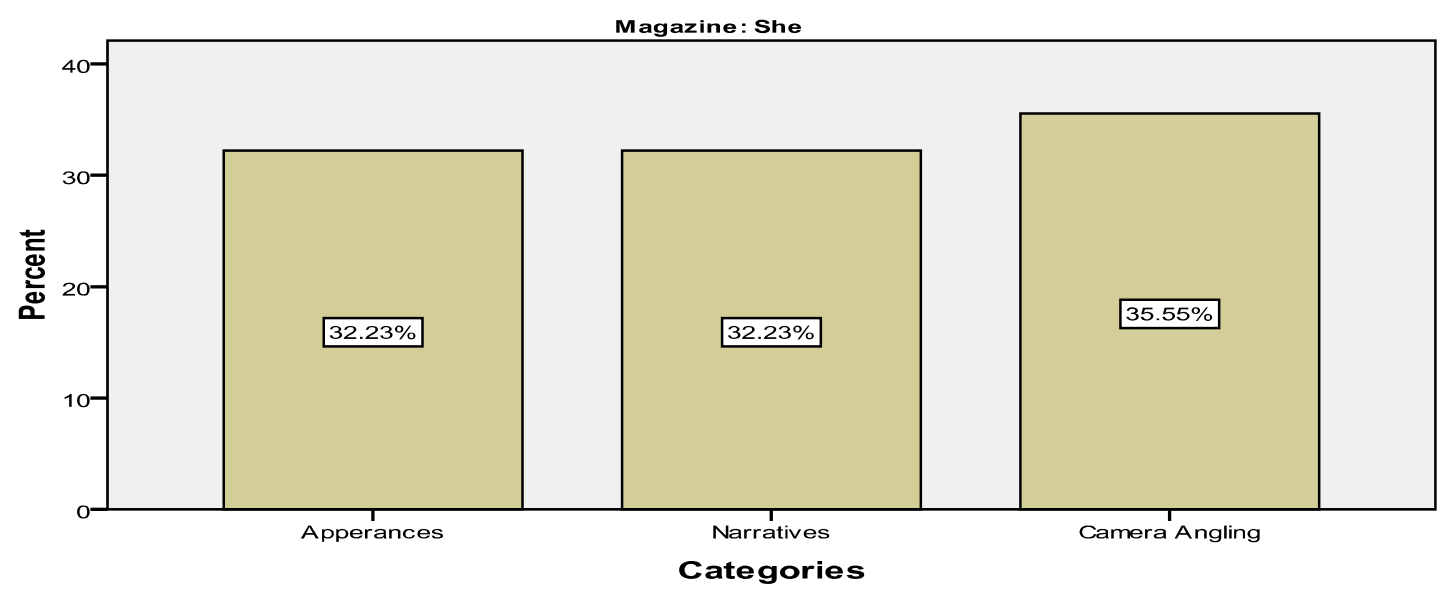

Cases weighted by data 
Table 3(c): Sub-categories of Appearance, Narratives and Camera Angling of 'She' magazine

subcategories

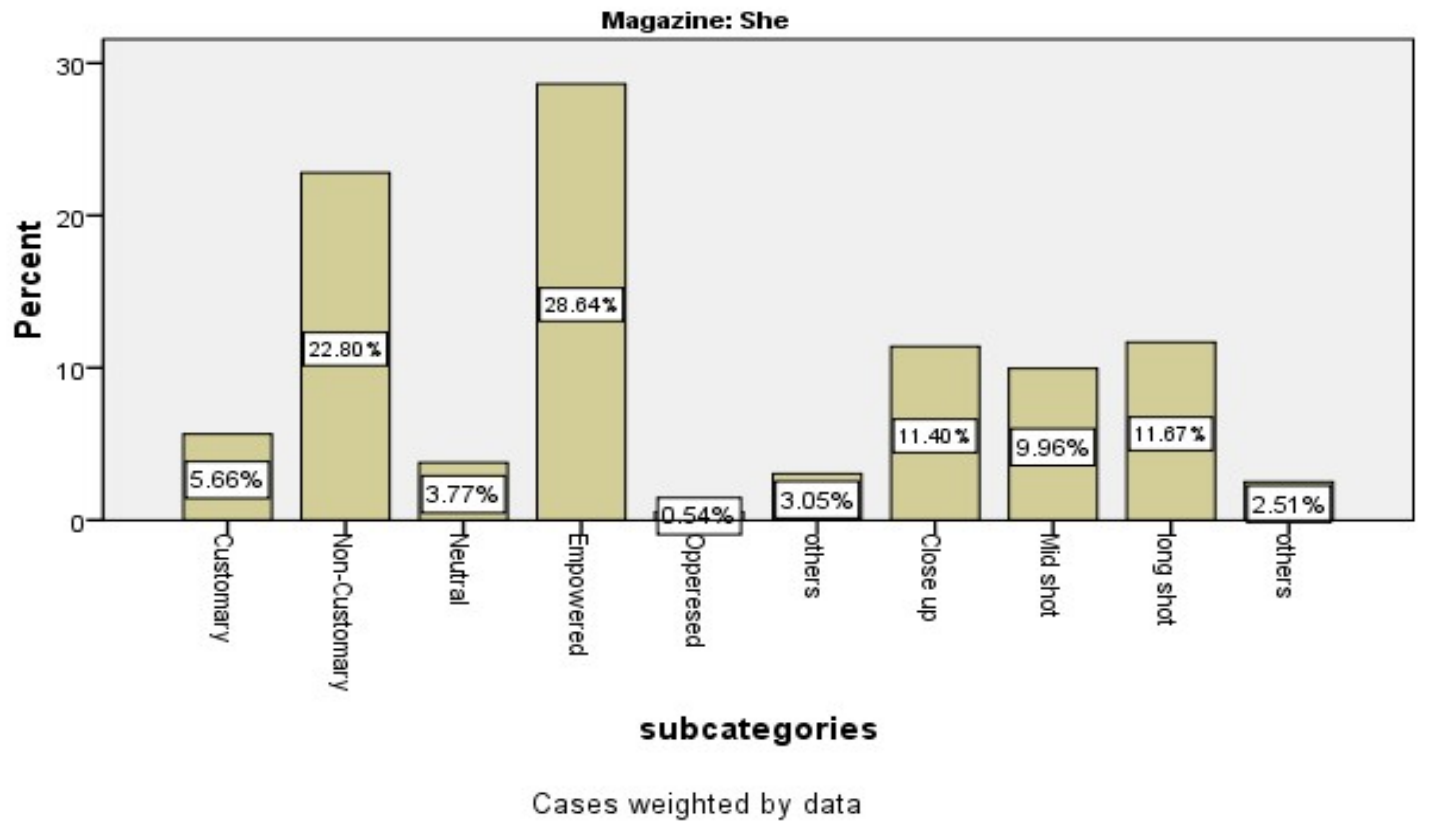

Table 3(c) of sub categories of magazine "She" shows appearances, narratives and camera angling of pictures published in 'She' magazine. Under the main category appearances total 359 which are $32.2 \%$ articles has published. 63 customary which are $5.7 \%, 254$ non-customary which are $22.8 \%$ and 42 neutral articles which are $3.8 \%$ have published. Under second key word narratives total 359 which are $32.2 \%$ articles have published. 319 empowered which are $28.6 \%, 6$ oppressed which are $5 \%$ and 34 others which are $3.1 \%$ articles have published in 'She' magazine. Under third category camera angling total 396 which are almost $35.5 \%$ articles with 127 closes up which are $11.4 \%$, $111 \mathrm{mid}$ sot which are $10.0 \%, 130$ long shot which are $11.7 \%$ and 28 others which are $2.5 \%$ have published in She magazine.

\section{Thematic Interpretation of In-Depth Interview}

\section{Role of Media towards Women}

The respondents argued that media is not playing any significant role at all. Magazines are portraying women for marketing purposes and to raise sales not to raise women issues. Two of the respondents argued, "If we talk about media in general it plays a significant 
role but particularly magazines are not playing any significant role as it is just about fashion." Whereas, four respondents said that magazines don't have any purposeful role, on the contrary newspaper articles are significant in highlighting the issues of women.

\section{Appearances of Women in Magazines}

Three of the respondents said that magazines have bold appearances to women depiction as narrating, "Appearances of women in magazines are not according to rituals and not confined with our traditions. Whereas three of them shared that magazines have unrealistic appearances of women as, "appearances for women are very happy, sexy and empowered. Magazines are nor representing traditional looks being very bold and sensual. Women are being represented as seductive in magazines and the real image of a woman is missing".

\section{Images of Women in Magazines Influence the Life of Women}

All the respondents admitted that these mediated images are influencing their lives drastically. The images are of women are making them much conscious about their looks and they feel persuaded by these images. One of the respondent replied, "I consider the packages in magazines for dressing and spas. I want to look nice and gorgeous like women of these magazines and want to look young and smart. Another respondent said, "I also want to be an empowered woman who can manage everything. I want to be a super mother of my kids." Yet another relied as, "I feel being persuaded by these magazines. As a lawyer I like to see the empowered images but magazines are representing erotic images of women as empowered that is objectification."

\section{Images of Real Life Issues of Working Woman in Magazines}

Magazines are not portraying women of our society. A respondent replied, "We have some traditions and values in our society. Have we ever seen so eccentric woman around us? No, this is the business of media's owners. Many respondents commented that images of working woman in magazines and woman in reality are different and reality behind the mediated images is unseen. Two of the respondents argued, "These images have visible contrast with real images of women. There are much differences in these mediated images of magazines and real image of woman. Another respondent replied, "There is text for women in magazines showing how woman is handling with her perfect picture and what is behind the text that is unseen". One on the respondent said, "The real lives of working and domestic women are miserable. Magazines are portraying the women of elite class setting the standards for others". 


\section{Magazines Represent Women as a Beauty Icon}

The magazines are representing women as a symbol of beauty. One of the respondent said, "Women have become commodity for magazines so they are using their bodies as an object to sell their magazines". Another replied, "Due to change in the time and necessity, the magazines are representing woman as beauty icon".

\section{Magazines Defining and Redefine the Role of Woman}

Many of the respondents agreed that depiction of women in the magazines as flawless women is redefining the role of woman in society and adding more tasks in the existing roles and responsibilities. Four respondents replied, "Magazines are constructing a flawless genius woman, possessing expertise in every aspect of life that is adding various tasks in her life". Five of the respondents highlighted the issue that media is streamlining the woman's role in the society and defining the role of women both domestically and officially that raise the expectations from women.

Expectations of males from women both professionally and domestically: All the participants agreed that due to mediated images of women the perceptions have been changed and males whether they are husbands or bosses, expect much more from a woman. A woman should be having qualities of multi-tasking who can move round the clock. The concept of wife is blurring with girlfriend and an image of super women is being emerged. Two of the respondents said, "The concept of wife is blurring and when the perceptions change the expectations changes accordingly." "Now the husband needs a perfect wife".

\section{Women in Mental Pressure and Confronting Challenges}

Majority of the respondents argued that as working women they have lot of pressures due to ideal mediated metaphors. They feel fatigue and more frustration due to such pressures. The women of the contemporary era are expected to have to perform in their best and expected to manage all the aspects of their lives well. One of the respondent said, "I have pressures in my life and to keep balance between work and home is big challenge." Another replied," I feel pressures from my work place so try to give my best to complete and side by side to remain fresh and active for family." Four of the respondents said that married working women do not find enough time for the children that is the biggest pressure. 


\section{Unaddressed Issue and Suggestions}

Majority of the respondents were of the opinion that the reconstructed images of women in media are causing conflicts and leading to more divorce rates in society. The respondents argued that the real challenges of working women are ignored, depiction of women in magazines is beyond reality. A few of the respondents asked for the need of responsibility from media and suggested to play its part to strengthen the women.

\section{Discussion and Analysis}

Media as a powerful tool have influences on the consumers and structures the opinions in the globalized world. Magazines not only provide a range of information but also constructs and redefines the identities of women and particularly making the narratives for the images of perfect woman. Social identity theory argues that the social context, to which an individual feels to be the part and belongs to, defines the one's self concept of being. The social context or category provides the attributes to the member of the group to think, feel and behave in certain ways. The comparisons within group or out of group determine the bases for self-regulation of individuals. The members of any social group are very active and motivated to adopt the behaviours and strategies to achieve and maintain in group and out group comparisons that ultimately favour the members and thus helps to define the concept of one's self. The theory posits self-categorization and self-enhancement as the processes involved in defining self. Theorizing the above assumptions from social identity theory (SIT) to implement in the context of mediated images of women it can be argued that media images serves as the context for the women to define and redefine their own concept of self. The mediated images of perfect and ideal women (mostly beautiful super women) narratives of magazines set the attributes for them to adopt. As the theory argues that women become the active members who compare theme selves within their own context and with the out-group members (the mediated images of women). This comparison results in the self-regulation of the women who find the ways and attributes from the media to define and redefine themselves. Referring to Lull (2000) the identities of an individual are highly influenced by media in postmodern era.

Magazines mostly show the images of idealist empowered women that contradict the real life practices of women. On the other hand, the idealist women images with perfect body shapes create a lot of challenges to women and they feel pressurized to meet the expectations from others. The images of women identified for them in magazines provide a viewpoint to think about themselves and thus helping to define and redefine their own identities. As social identity theory argues that social institutions uphold cultural hegemony and provide us socially constructed ways of seeing and making sense of society. Self-identity, associated with self-understanding, involves self believe that is 
narratives of the self. So magazines set the narratives for women to see themselves in certain ways. These constructed narratives for women set the standards in the social context that leads towards the expectations from society towards women. The women who include themselves among the part of constructed images of media are considered as in the group. Groups are socially constructed to maintain identities. Identity construction and representation of women in the magazines is the discourse of dominating powers in which women are revealing themselves at every moment. Narrating a self is the discourse of others (Gergen, 2003), this discourse created through social comparisons and over expectations from postmodern women.

Theorizing social expectation theory it can be argued that the mediated identities of women create expectations from women to fulfil. The women are expected to meet and maintain certain standards which create exceeding pressures for woman. The women are expected how they should look like and how to behave. The mediated images represent a glamorous picture of a female hero with huge of duties and expectations to meet all with perfection. The mediated concept of empowered women creates social expectations. In the interviews of women it was revealed that these expectations create family disorders. Husband wants a thin ideal wife who must be excellent in domestic duties and must be presentable socially. The narrative and the appearances in the magazines are creating challenges and pressures for working women in maintaining their own identities. Magazines have made the women an object/beauty icon for client's and customers' attentions and to fulfill their dreams of women too who wants to be alike. Media is littered with unrealistic standards making it normal for woman to live up this ideal which is a direct cause of psychological anxiety among the societal layers which is again fabricated by male inherited society (Dittmar et al 2004). Anxiety and depression are created by magazines. The mediated empowered women are much far from empowered women in real. The working women in the magazines don't exist in real. Even woman's insecurities are alarming as media have made the woman a beauty icon, sexual object and a business commodity. The alienation of postmodern women assisted with technological techniques where the power constructs the women identities globally. These globally constructed identities have produced a web of challenges for working women which are not being addressed in the contents of magazines.

\section{Conclusions}

The study comes up with the conclusion that the discourses of mediated images in the magazine are creating unrealistic images of women. The mediated images of magazines and the real life issues and status of women are quite different. The mediated images show women in the terms of ideal super women who should meet certain standards set by media itself and that create challenges and social pressures for women in their real life. Crisell (2002) argued that images of media teach us to feel not to think and we accept the 
images as reality. This unseen difference between appearance and reality is creating judgments and social comparisons in lives of working women which is ignored area in the research of this domain. The media is streamlining the roles for women that are having influences on the lives of women. The representations of women in magazines are creating an illusion of idealist women, whereas postmodern feminist believed the survival of women in better ways not oppressed or exploited one.

\section{References}

Berberick, S. N. (2010). The Objectification of Women in Mass Media: Female SelfImage in Misogynist Culture. The New York Sociologist, vol.5:1, pp.1-15.

Becvar, D. S., \& Becvar, R. J. (2006). Family Therapy: A Systemic Integration Boston. MA: Pearson Education.

Byerly, C. M. (1999). News, Feminism and the Dialectics of Gender Relations. Mediated Women. Representations in Popular Culture, Cresskill: Hampton Press, pp.383-403.

Brummett, B. (1984). Burke's Representative Anecdote as a Method in Media Criticism. Critical Studies in Media Communication, vol.1:2, pp.161-176.

Buzzanell, P. M., Meisenbach, R., Remke, R., Liu, M., Bowers, V. \& Conn, C. (2005). The Good Working Mother: Managerial Women's Sense making and Feelings about Work-Family Issues. Communication Studies, vol.56:3, pp.261-285.

Cashmore, E. (2014). Celebrity Culture. Routledge.

Crisell, A. (2002). An Introductory History of British Broadcasting. Routledge.

Devereux, E. (2013). Understanding the Media. Sage.

Dittmar, H., \& Howard, S. (2004). Professional hazards? The Impact of Models' Body Size on Advertising Effectiveness and Women's Body-Focused Anxiety in Professions that Do and do not Emphasize the Cultural Ideal of Thinness. British Journal of Social Psychology, vol.43:4, pp.477-497.

Eisend, M. (2010). A Meta-Analysis of Gender Roles in Advertising. Journal of the Academy of Marketing Science, vol.38:4, pp.418-440. 
234 Challenges and Pressures of Mediated Images: Exploring Representation of Postmodern Women in the Leading Magazines of Pakistan and Understanding the Discourses of Working Women

Elliott, D. (2003). Moral Responsibilities and the Power of Pictures. Images that Injure: Pictorial Stereotypes in the Media. London: Praeger, pp.7-14.

Muthusamy, E. (2009). Problems Faced by the Working Women in the Era of Globalisation.

Foucault, M. (1980). Power/knowledge: Selected Interviews and other Writings, 19721977. Pantheon.

Guest, G., Bunce, A. \& Johnson, L. (2006). How Many Interviews are Enough? An Experiment with Data Saturation and Variability. Field Methods, vol.18:1, pp.59-82.

Gerber, R. (2009). Barbie and Ruth: The Story of the World's Most Famous Doll and the Woman who Created Her. New York, NY: Collins Business.

Garner, D. M., Garfinkel, P. E., Schwartz, D. \& Thompson, M. (1980). Cultural Expectations of Thinness in Women. Psychological Reports, vol.47:2, pp.483-491.

Gauntlett, D. (2008). Media, Gender and Identity: An Introduction. Routledge.

Goldman, A. I. (1992). In Defense of the Simulation Theory. Mind \& Language, vol.7:1-2, pp.104-119.

Gergen, M. M. E. (1988). Feminist Thought and the Structure of Knowledge. New York University Press.

Grogan, S. (1999). Body Image: Understanding Body Dissatisfaction in Men, Women and Children. New York: Routledge.

Hall, S. (1997). The Work of Representation. Representation: Cultural Representations and Signifying Practices, vol.2, pp.13-74.

Hall, S. (1997). The Spectacle of the Other. InS. Hall. Representation: Cultural Representation and Signifying Practices(Ed.). London: Sage. 223-90.

Harper, B. \& Tiggemann, M. (2008). The Effect of Thin Ideal Media Images on Women's Self-Objectification, Mood and Body Image. Sex Roles, vol.58:9-10, pp.649-657.

Harris, C. R. \& Lester, P. M. (2002). Visual Journalism: A Guide for New Media Professionals. Allyn \& Bacon.

Hundley, H. L. (2012). Mediated Portrayal of Masculinities in US Media. 
Hogg, M. A., Terry, D. J. \& White, K. M. (1995). A Tale of Two Theories: A Critical Comparison of Identity Theory with Social Identity Theory. Social Psychology Quarterly, pp.255-269.

Hornsey, M. J. (2008). Social Identity Theory and Self-Categorization Theory: A Historical Review. Social and Personality Psychology Compass, vol.2:1, pp.204-222.

Jain, J. (2011). Indigenous Roots of Feminism: Culture, Subjectivity and Agency. SAGE Publications India.

Baudrillard, J. (1994). Simulacra and Simulation. University of Michigan Press.

Lyotard, J.F. (1984). The Postmodern Condition: A Report on Knowledge (G. Bennington and B. Massumi, Trans.) Minneapolis. MN: University of Minnesota Press

Lilly, J. D., Duffy, J. A. \& Virick, M. (2006). A Gender-Sensitive Study of McClelland's Needs, Stress and Turnover Intent with Work-Family Conflict. Women in Management Review, vol.21:8, pp.662-680.

Lull, J. (2000). Media, Communication, Culture: A Global Approach. Colambia University Press.

McRobbie, A. (2008). Young Women and Consumer Culture: An Intervention. Cultural Studies, vol.22:5, pp.531-550.

Meyer, M. (1999). Facturing Women. In M. Meyers(Ed.). Mediated Women: Representation in Popular Culture. Hampton Press, Cresskill, pp.3-23.

Nagi, P. (2014). Projection of Women in Advertising: A Gender Perception Study. International Journal of Managerial Studies and Research (IJMSR), vol.2:9.

Orbach, S. (1978). Fat is a Feminist Issue: The Anti-Diet Guide to Permanent Weight Loss. New York: Berkley Book.

Orgad, S. (2017). The Cruel Optimism of the Good Wife: The Fantastic Working Mother on the Fantastical Treadmill. Television \& New Media, vol.18:2, pp.165-183.

Sarkar, S. (2014). Media and Women Image: A Feminist Discourse. Journal of Media and Communication Studies, vol.6:3, pp.48-58. 
Signorielli, N., McLeod, D. \& Healy, E. (1994). Profile: Gender Stereotypes in MTV Commercials: The Beat Goes On. Journal of Broadcasting \& Electronic Media, vol.38:1, pp.91-101.

Spender, D. (2001). Man Made Language. London: Rout ledge.

Stets, J. E. \& Burke, P. J. (2000). Identity Theory and Social Identity Theory. Social Psychology Quarterly, pp.224-237.

Sundaresan, S. (2014). Work-Life Balance-Implications for Working Women. OIDA International Journal of Sustainable Development, vol.7:7, pp.93-102.

Suleman, M. (2018). Top Highest Paying Jobs in Pakistan. Retrieved from: http://www.fincyte.com/highest-paying-jobs-in-pakistan/

Tsichla, E. \& Zotos, Y. C. (2013). Gender Stereotypes in Cypriot Magazine Advertisements: A Comparison of Single and Relationship Portrayals. In Proceedings of the 18th International Conference on Corporate and Marketing Communication, April (pp. 11-12).

Tuchman, G. (2000). The Symbolic Annihilation of Women by the Mass Media. In Culture and Politics (pp. 150-174). Palgrave Macmillan, New York.

Walsh-Childers, K. (2003). Women as Sex Partners. Images that Injure: Pictorial Stereotypes in the Media, vol.2, pp.141-48.

Yang, J. (2011). Gender Differences in Advertisements: A Study of Adjectives and Nouns in the Language of Advertisements. Yasmin, M., Sohail, A. \& Mangrio, R. A. (2015). Myths Broken or Sustained: Representation of Women Victims in Pakistani media. Open Journal of Social Sciences, vol.3:07), pp.209.

Yin, B. \& Pryor, S. (2012). Beauty in the Age of Marketing. Review of Business \& Finance Case Studies, vol.3:1, pp.119-132.

Zawisza, M. \& Cinnirella, M. (2010). What Matters More-Breaking Tradition or Stereotype Content? Envious and Paternalistic Gender Stereotypes and Advertising Effectiveness. Journal of Applied Social Psychology, vol.40:7, pp.1767-1797.

Zoonen, V. (1996). Feminist Media Studies. London: Sage. 


\section{Appendices}

Appendix-I

Coding Sheet

Topic: Challenges And Pressures of Mediated Images of Women: Exploring Postmodern Women's Representation in Leading Pakistani Magazines in Highlighting Discourses of Working Women

Year:

Magazine:

\begin{tabular}{|c|c|c|c|c|c|c|c|c|c|c|c|c|c|c|c|}
\hline Units & Categories & $\begin{array}{l}\text { Sub } \\
\text { Categories }\end{array}$ & January & February & March & April & May & June & \begin{tabular}{|l|l} 
July \\
\end{tabular} & August & September & October & November & December & Total \\
\hline \multirow{6}{*}{ Article } & \multirow{3}{*}{ Appearances } & \begin{tabular}{|l} 
Customary \\
\end{tabular} & & & & & & & & & & & & & \\
\hline & & \begin{tabular}{|l|} 
Non \\
Customary
\end{tabular} & & & & & & & & & & & & & \\
\hline & & Neutral & & & & & & & & & & & & & \\
\hline & \multirow{3}{*}{ Narratives } & \begin{tabular}{|l} 
Empowered \\
\end{tabular} & & & & & & & & & & & & & \\
\hline & & \begin{tabular}{|l|} 
Oppressed \\
\end{tabular} & & & & & & & & & & & & & \\
\hline & & \begin{tabular}{|l|l|} 
Others \\
\end{tabular} & & & & & & & & & & & & & \\
\hline \multirow{4}{*}{ Pictures } & \multirow{4}{*}{$\begin{array}{l}\text { Camera } \\
\text { Angling }\end{array}$} & Close-Up & & & & & & & & & & & & & \\
\hline & & \begin{tabular}{|l|} 
Med Short \\
\end{tabular} & & & & & & & & & & & & & \\
\hline & & \begin{tabular}{|l|} 
Long Short \\
\end{tabular} & & & & & & & & & & & & & \\
\hline & & \begin{tabular}{|l|} 
Others \\
\end{tabular} & & & & & & & & & & & & & \\
\hline
\end{tabular}




\section{Appendix-II}

\section{Questionnaire of the Qualitative In-Depth Interviews}

The following 1-12 open-ended questions for interviews were mainly developed.

i. $\quad$ Does the media play a significant role for women in the society?

ii. Which type of appearances of women do you see mostly in magazines specifically?

iii. How do these images of women in magazines influence your life? (Probing: How and why? Feel inspiration or persuaded? Idealise the images?)

iv. Are these images of magazines representing the real lives of women in the society?

v. Are magazines representing women as beauty icons?

vi. Are these images of women in lifestyle magazines defining and redefining the role of women in the society?

vii. Does the erotic representation of the working women in lifestyle magazines shaping male's perception about women in the society?

viii. Do you feel that males are expecting more from women at workplace and at the domestic level (Probing: What kind of expectation?)

ix. What kind of pressures do you feel psychologically and physically from your boss, husband kids or peers?

x. What kind of challenges do you feel in maintaining your status?

xi. Do fashion and lifestyle magazines describe issues of the working women?

xii. What are unaddressed issues in the presented images of magazines?

Dr. Sumera Batool is an Assistant Profess in the Department of Mass Communication, Lahore College for Women University, Lahore.

Sadia Majeed is Visiting Lecturer in the Department of Mass Communication, National University of Modern Languages, Lahore. 